\title{
Empire's culture in Fredric Jameson, Edward Said and Gayatri Spivak
}

\begin{abstract}
Aijaz Ahmad's landmark 1992 book In Theory argues that materialist and postcolonial cultural studies are fundamentally incompatible projects. ${ }^{1}$ Whatever Ahmad may aver, relations between materialism and postcolonialism are more complex than mere incompatibility. For instance, Said's essay on empire in Jane Austen's Mansfield Park appears in a recent book titled Contemporary Marxist Literary Criticism, where the editor Francis Mulhern defines Said as 'writing in solidarity with Marxism rather than as a declared exponent.'2 Said's essay originally appeared in a volume of critical essays on Raymond Williams, whose insularly English work on the country and the city is both extended and revised by Said to account for the historical colonial conditions of English self-representation. ${ }^{3}$ While Said's historicism establishes his solidarity with leftist cultural criticism, his constructions of space and his (variable) aestheticism do not.

In this chapter I will discuss Said's work alongside that of two influential thinkers who share equally complicated relations with materialist theory: Gayatri Chakravorty Spivak and Fredric Jameson. Spivak, a selfdesignated 'Marxist-feminist-deconstructionist', is highly regarded as one of the key practitioners of post-colonial theory; Jameson is one of the leading left theorists of culture in the USA. These three thinkers have each produced an impressively large and wide-ranging opus of critical thought. My concern here, however, is exclusively with their respective analyses of nineteenth- and early twentieth-century British imperialism. ${ }^{4}$ I want to suggest the strengths and the limitations of their respective theorisations in relation to a materialist postcolonial theoretical practice. This is best achieved, I believe, by an approach that combines immanent critique with a comparative technique whereby the three thinkers are set in dialogue with one another. I will here briefly outline their respective analyses, before proceeding to sections that focus on their conceptualisations of imperial culture and of space.
\end{abstract}


If Said is prompted to correct and extend the work of Raymond Williams, Spivak is likewise moved to challenge the work of Terry Eagleton for its insularly national account of Jane Eyre's class dynamics. Jameson writes from a different but equally revisionary impulse: to extend Lukácsian aesthetics to include the impact of empire building on metropolitan art, and to amplify Lenin's conceptions of imperialism as the last stage of capitalism. Like Jameson, Said and Spivak are also motivated by expressly contemporary political goals. Spivak offers a strategic intervention against contemporary Anglo-European bourgeois feminism. This animates her discussion of how Jane Eyre's conceptions of European female individualism are predicated on and perpetuate the subordination of non-European women. Said works towards a humanistic politics and a contrapuntal intellectual culture that, for him, will provide progress beyond the contemporary deadlock of imperialism and nationalism.

While all three thinkers perceive imperialism as a matrix of domestic culture and consciousness, their definitions of imperialism itself differ. Said's derive from the notion of geo-political domination. His predominant, Williamsesque concern is with metropolitan 'structures of feeling' and how geographical expansionism influences them. ${ }^{5}$ The anti-foundationalist Spivak does not offer an explicit definition of imperialism, but addresses instead its manifestation as 'a territorial and subject-constituting project'. This leads her to analysis of how the 'discursive field of imperialism' can produce 'ideological correlatives for the narrative structuring' in fiction. Whereas Said and Spivak are interested in the pattern of fictional narrative, Jameson is interested in style and language. His discussion of E.M. Forster's Howards End discerns a newly spatialised language as compensation for the existential losses incurred by overseas expansion. Jameson like Lenin defines imperialism as the departure from 'the classical stage of national or market capitalism' into an international system of production and consumption.

Jameson argues that this system has a singular impact upon metropolitan-national identity. For Spivak, in contrast, imperialism though ideologically hegemonic is not genderless. Her theorisation of Jane Eyre pursues a sexual differentiation of ideology into the registers of 'childbearing' and 'soul making'. Spivak's argument develops through her insights into the divergent forms of Bertha Mason's delegitimation by, respectively, Jane and Rochester. Jane perceives Bertha as more animal than human, thereby aligning Jane all the more emphatically with the sphere of humanity and its reproduction. Rochester, in contrast, per- 
ceives Bertha in missionary-colonial terms. He is thereby associated with divinity rather than humanity; his release from his missionary (marital) duties is presented as an injunction issuing from God himself (pp. 266-7). It is the convergence of these female and male imperialist registers that provides the primary animus for the narrative's movement. Their divergence is just as significant at the novel's conclusion, when the 'tangent narrative' of St John Rivers's heroic missionary life in Calcutta emphasises the incommensurability of these two registers. The case of St John Rivers links the dynamic of 'soul making' to the Kantian categorical imperative: when recast as 'make the heathen into a human so that he can be treated as an end in himself', the imperative becomes accessory to imperialism (p. 267).

Spivak argues clearly and persuasively that the interpellation of imperial subjects is sexually specific. This presents an important challenge to the gender-blindness of both Said and Jameson. Spivak's approach also includes the possibility of effective metropolitan opposition, a possibility that Said and Jameson disallow. That Spivak can conceive of coherent oppositionality is a consequence of her deconstructionist tenets and her primarily philosophical focus on Kantian notions of subject formation. Thus she reads Mary Shelley's Frankenstein as an example of oppositional critique. This is articulated in the way it criticises Victor Frankenstein for his substitution of theoretical for practical reason, and his attempt to invent'a putative human subject out of natural philosophy alone' (p. 275).

Jane Austen's Mansfield Park, like Charlotte Brontë's Jane Eyre, charts the movement of a woman from social margins to centre. The centre in this case is the country estate of Mansfield Park, which owes its maintenance to the sugar plantations of Antigua. Said does not view the novel's ideology as sexually differentiated; his analysis takes the estate, and the narrative, to operate as a coherent whole, comprised of an ensemble of female and male figures. This is a consequence of his conception of metropolitan culture as spatially fixed and singular. While Jameson sees the metropole as united in its sensory and existential experience, Said sees it as joined by ideology, contending that 'there was scarcely any dissent, any departure, any demurral from them: there was virtual unanimity that subject races should be ruled ... With few exceptions, the women's as well as the working-class movement was proempire' (p. 62).

Said's conception of Mansfield Park as an ideological unit, affirmative of empire, is also a consequence of his progressive view of social and 
cultural history. For according to Said, it is only with modernism that narrative structure admits of formal and ideological divisibility, and becomes capable of ironic (not oppositional) awareness of imperialism's political limitations. Said's is the most ambitious and methodologically eclectic of the three works, concerned as it is with the novel's dynamics of spatial movement, its ideological systems of morality and aesthetics, its characters' trajectories and its materialist contextualisation through contemporary Caribbean political and economic processes. At the same time Said pursues an argument about the function of Austen's novel in enabling subsequent material practices of imperialism. This ambitiousness contributes an admirably broad cultural understanding of imperialism. It also creates some tensions, arising in particular from the emphasis on a spatial model of ideology.

\section{Metropolitan culture and imperialism}

Spivak, Said and Jameson differ significantly over three key issues: imperialism's date of origin, its relation to aesthetic modernism and its relation to Enlightenment humanistic philosophy. Said tends to date its origin in the eighteenth century, although at times he identifies the seventeenth and even sixteenth centuries as its point of inception. For Jameson, imperialism is a strictly nineteenth-century phenomenon. Both recognise the magnitude of the changes that European cultural, economic and political practices underwent in the late nineteenth century, but while for Said this period merely expresses a new stage of imperialism, for Jameson this marks its beginning. Jameson presupposes that the classical, national stage of capitalism did not involve (let alone depend upon) colonial production and that it was only when formalised (with the 'Scramble for Africa') in the late Victorian era that imperialism made any significant impact on aesthetic culture. To both of these assumptions Said offers effective rebuttal, demonstrating the significance of colonial expansion for metropolitan economic and cultural formations throughout the nineteenth century.

Jameson and Said both consider modernism a compensatory and ultimately collusive reaction to empire. Discussing Howards End, Jameson acknowledges Forster's anti-imperial sentiments, but argues that they are undermined by the sensory impact of expansionism on the novelist. Such an impact is for Jameson an inevitable consequence of the economy: 
colonialism means that a significant structural segment of the economic system as a whole is now located elsewhere, beyond the metropolis, outside of the daily life and existential experience of the home country ... Such spatial disjunction has as its immediate consequence the inability to grasp the way the system functions as a whole ... no scientific deductions on the basis of the internal evidence of First-World data, can ever be enough to include this radical otherness of colonial life, colonial suffering and exploitation, let alone the structural connections between that and this, between absent space and daily life in the metropolis. (pp. 50-1)

Jameson's phenomenological language stresses the empirical materiality of the metropolitan senses. This same empiricism structures Jameson's definitions of modernism as a biological compensation, referring as he does to 'the work of some new modernist language on our bodies and our sensorium that is its precondition' (p. 55).

Because both the human body and the geographical nation have physical substance Jameson seems to assume them to be immune from the processes of subjective mediation: they are not themselves produced by and experienced as ideologies but they instead serve as the empirical basis from which subjectivity emerges. The human sense of existence is, it seems, entirely and directly constituted by the sensations of the physical body. And since, for Jameson, the nation is the natural limit of the existential-sensory subject, then whatever occurs outside of that national space must consequently be unbridgeably 'other' to it. Thus, however discrepant metropolitan people's social, economic, political and intellectual positions, their existential-cum-physiological experience of imperialism is identical. In rendering imperialism a fixed fusion of 'objective' economic-productive with 'objective' physiological processes, Jameson problematically naturalises and depoliticises the phenomenon.

In sharp contrast, Said argues that modernism's existential anxiety was a response in part to the importation of colonial cultural materials, in part to the knowledge of colonial resistance movements, both of which threatened metropolitan cultural and political security. He concurs with Jameson that modernism was fuelled by a desire to compensate for a fracturing of self-identity, substituting aesthetic for social totalities. But whereas Jameson emphasises the sense of loss - modernist metropolitans as victims of capitalism's splitting - Said emphasises the sense of domination underlying modernist production; the formal experimentation 
substituting art and its creations for the once-possible synthesis of the world empires. When you can no longer assume that Britannia will rule the waves forever, you have to reconceive reality as something that can be held together by you the artist. (p. 229)

Said's formulations can be made to invert Jameson's. The metropole was flooded during the period of modernism with representations of imperialism itself as a system and totality, with representations of its contestation by colonised peoples and with examples of colonised cultures and knowledge-systems. This lowering of spatial boundaries between colony and metropole in the flows of capital, information and culture was matched by an increase in the accessibility to metropolitans of colonial travel, employment and sojourn. ${ }^{6}$ From this it becomes possible to argue that what aroused modernist perceptions of imperialism as constituting a 'representational dilemma' and an existential loss was the way late nineteenth-century imperialism broke down rather than introduced absolute, spatial boundaries between countries and peoples.

On the connections between Enlightenment humanistic culture and the material practices of imperialism, Said offers a variety of conceptual possibilities, while Spivak is noncommittal. Spivak asserts that Kant's categorical imperative 'can be travestied in the service of the state', to 'justify the imperialist project', resulting as we have already seen in the violence of the missionary imperative to constitute 'heathens' as human subjects by rendering them Christians (p. 267). That such a travesty is possible Spivak attributes to 'the dangerous transformative power of philosophy' itself; the travesty 'exists within its lineaments as a possible supplement' (p. 279). Such an explanation is valuable in its non-reductiveness; unlike a number of post-structuralist thinkers Spivak does not charge Enlightenment rationality per se with being categorically 'violent'. Indeed, it is for her possible to conceive of a humanistically progressive Kantianism. Shelley's Frankenstein provides one example through its fidelity to Kant's schematic division of human faculties into pure reason, practical reason and judgement.

That philosophy can be travestied is clearly explained by Spivak, but not why, nor how; she is inattentive to the dynamics of philosophy's mediation by 'the state', and within aesthetic representation. Why Brontë's text can be read as receptive to imperialism's travesty and why Shelley's can not, and what it means for an understanding of both culture and the state that such unevenness of reception can occur, are not questions with which 
Spivak is concerned. She avoids reductiveness in her characterisation of Kantian philosophy, only to transfer such reductiveness to the notions of the state (as identical with 'the imperialist project') and aesthetic culture (as indistinguishable from ideology, of which it presents allegorical examples).

Indeed, although Spivak is careful never to define imperialism as such, but instead focuses on its ideological operations and effects, a general definition (and date) emerges anyway. This comes with her postulation of its historical mechanics:

No perspective critical of imperialism can turn the Other into a self, because the project of imperialism has always already historically refracted what might have been the absolutely Other into a domesticated Other that consolidates the imperialist self. (p. 272)

It is difficult to reconcile the notion of the 'always already' with that of 'historical' refraction. The result is a kind of constitutive indeterminacy whereby Spivak's gestures towards historical particularity ambiguously affirm both a contingent materialism and an absolute idealism. European history happens to coincide with the hegemony of imperialism, such that the sum total of European history is inextricable from an imperialist trajectory that continues in overdetermined ways to control the conditions of contemporary cultural and intellectual production. At the same time, it seems, the designation 'imperialism' applies to the conditions of narrative, representation and knowledge production themselves.

Either way, the process of imperialism is viewed as the precondition of a sense of (European or theoretical) narrative Self, and is predicated on a distorting utilisation of the Other. Imperialism then is not only the explicit practice of power. It is also the disavowal of the possession of power through the belief in one's ability to know and represent the Other; to pursue such a narrative representation is necessarily to turn the Other into a version of oneself. This formulation does not admit of any notion of possible or progressive mediation. The phenomenon of imperialism/domination derives, in a sense, from the possibility of movement per se: it is 'the dangerous transformative power' of Kantian philosophy that enables its instrumentalisation by the state, enables the categorical imperative 'to be mistaken for' (that is, to occupy the place of) the hypothetical imperative.

The preferable political option for Spivak is, it seems, for subjects, like Kantian imperatives, to learn their limits, stay in their naturally 
separate places, as taught by Shelley's Frankenstein. The spatialised conception of subjectivity as occupying a distinct, fixed and rightful domain, is marked here; imperialism becomes the by definition expansionist and dominatory movement across these delineated territories. It is no accident that Spivak should repeatedly refer to imperialism's 'territorial and subject-constituting projects' in the same breath: the two projects are seen as flipsides of the same geo-spatial coin. If imperialism expresses a highly abstracted will-to-power, it is simultaneously identified with the highly specific ideology, historical period and region selected by Spivak for her literary discussion. She privileges the ideology of Christian missionary imperialism, the period of early to mid nineteenth century, and the terrain of India (to a lesser extent the Caribbean). Admittedly she presents this choice as strategic rather than theoretical. But, in the absence of any acknowledged alternative regions and periods, these examples take on the status of theoretical primacy and general allegory. Thus, the critic can be caught in a double bind: imperialism's theoretical definition as the totality of Western history/knowledge/power is effectively at one with its definition as mid-Victorian missionary ideology. 7

Said's account of the relations between Western aesthetic representation, narrative and empire is strikingly variable. Detailing both their historical and structural dynamics, at one point he argues

We are not yet at the stage where we can say whether these [cultural] structures are preparations for imperial control and conquest, or whether they accompany such enterprises, or whether in some reflective or careless way they are a result of empire. We are only at a stage where we must look at the astonishing frequency of geographical articulations in the three Western cultures that most dominated farflung territories. (p. 61)

Said may here emphasise the undecidability of the relationship, but elsewhere he equally assertively characterises culture as historically precedent to imperial political practice and enabling of it. ${ }^{8}$ And elsewhere he casts these territorial practices as precedent to the cultural articulations. ${ }^{9}$ Still elsewhere, we are told that the two were mutually fortifying and symbiotic. ${ }^{10}$

Two theoretical perspectives underlie this contradictory diversity. One is a Foucauldian notion of the cultural and the political practices as expressive of the same power dynamic: 
there is a convergence between the great geographical scope of the empires ... and universalizing cultural discourses. Power makes this convergence possible; ... [W] ith it goes the ability to be in far-flung places, to learn about other people, to codify and disseminate knowledge, to characterize, transport, install, and display instances of other cultures, and above all to rule them. (p. 130)

The second is a Gramscian notion of culture as part of the ideological weaponry of imperialism:

imperialism [is] a process occurring as part of the metropolitan culture, which at times acknowledges, at other times obscures the sustained business of the empire itself. The important point ... is how the national British cultures maintained hegemony over the peripheries. How within them was consent gained and continuously consolidated for the distant rule of native peoples and territories? (p. 59)

Said's Foucauldianism here deploys a predominantly spatial, formal construction of imperial culture, which in jettisoning the conceptual machinery of historical and economic determinations permits culture to be thought of both as antecedent, subsequent to and contemporary with political expansion. Said not infrequently uses spatial figures to convey this: 'the novel steadily ... opens up a broad expanse of domestic imperial culture without which Britain's subsequent acquisition of territory would not have been possible' (p. 114). Or:

The British international identity, the scope of British mercantile and trade policy ... provided irresistible models to emulate, maps to follow, actions to live up to. Thus representations of what lay beyond insular or metropolitan boundaries came, almost from the start, to confirm European power. (p. 127)

The more Gramscian tenets of Said's analysis, in contrast, are concerned with the contents, as opposed to the spatial shape or form, of cultural ideology, and how they come to be instrumentalisable by specific blocs of political agents and authorities. Such an approach seems to support a view of socio-economic imperial power as able both to utilise existing ideological resources in culture and to invent them. ${ }^{11}$

I find it regrettable that the Gramscian elements in Said's thought are subdued throughout Culture and Imperialism. Although they might 
facilitate further theorisation of social agency, and its relationship to imperial economic and political domination, the Gramscian elements operate more rhetorically than conceptually in this work. Were Said to follow through his Gramscianism, he might be led to a more extended account of how ideology operates. He would be able then to explain why it was that ideologies of imperialism were so predominant in metropoli$\tan$ Britain, or alternatively to perceive these ideologies as rather more contested than he allows. ${ }^{12}$

The conceptions of Gramsci indeed might offer a potential resource for extending the thought of all three thinkers. In Gramsci's notion of 'articulation' one can find ways to escape the absolutism of historical teleology in Said and Jameson, and the equally absolutist basis of Spivak's allegorical methodology. Gramsci's analysis of the relations between state, civil society and ideology might help to explain the mechanisms whereby the state in Spivak's contention distorts Kant's categorical imperative. Gramsci's engagement with the interrelations between politics and economics also suggests ways to avoid Jameson's neglect of politics. ${ }^{13}$

\section{Literature and the aesthetics of space}

Jameson and Said share a similar conception of the aesthetic function and meaning of space. This distinguishes them from Spivak, who views spatial representation as dictated by ideology. Jane Eyre prefers to situate herself not within the 'sanctioned architectural space of the ... drawing room' to which the family retires, but instead in the 'small breakfast room' which adjoins it, and avails herself of the contents of the bookcase placed in this room. This illustrates her constitution as a marginalised and private subject. Spatial location, in other words, is determined by the book's ideology of feminist romantic individualism.

In sharp contrast, Jameson and Said view physical space as constitutive of, not constituted by, their novel's ideologies. Jameson, as we have seen, argues that Forster's consciously anti-imperialist sentiments in Howards End are belied by his stylistic, sensuous and aesthetic responses to empire's spatial dynamics. Jameson's 'space' initially refers to that which carries physical matter. Thus, he argues that the image of the 'Great North Road ... suggestive of infinity' with which Howards End opens condenses philosophical thoughts into 'essentially a spatial representation and a spatial perception', exposing philosophy's dependence 
on space for its expression. 'Spatial perception' here apparently denotes 'perception of physical matter' rather than a physically derived mode of general perception. Space, that is, here serves as object, not adjective. Jameson proceeds to argue that what marks this episode as proto-modernist is the image's indeterminacy:

it is undecidable whether the Great North Road is the tenor or the vehicle; whether the roadway is intended ... to concretize the nebulous metaphysical concept, 'infinity', and by a momentary transfer of its visual properties to make that vague but lofty word a more vivid player in the textual game; or whether, on the other hand, it is rather the metaphysical prestige of the more noble Idea that is supposed to resonate back on the banal highway, lending it noumen and thereby transforming it into the merest promise of expressivity without having to affirm it as some official 'symbol' ... Modernism is itself this very hesitation; it emerges in this spatial gap within Forster's figure. (pp. 54-5)

Space as a figurative term for the 'gap' between phenomenal and noumenal modalities follows space's meaning as phenomenal matter. The next stage in the argument introduces a third notion: 'The solution to this contradiction, which we call "style", is then the substitution of a spatial or perceptual "meaning" ... for the other kind ...' (p. 55). Here 'spatial' shifts to denote 'the initial ground' (basis) of meaning. Jameson repeats the semantic indeterminacy he ascribes to modernism, exploiting the ambiguity sanctioned by this abstracted term. 'Space' is designated as that which forms the material object of the modernist gaze, that which constitutes modernism's subjective basis, and that which constitutes the gap between these objective and subjective qualities. 'Space' becomes less a term for a physically material, sensory quality than a mystical term for whatever escapes, or is not reducible to, tangible and rational 'meaning'.

Jameson partially resolves these contradictions through his dialectical methodology. Contending, with Lukács, that aesthetic representation 'is governed by an intention towards totality', he ultimately casts the aesthetically dense, physically substantial yet indeterminate image of the Great North Road as 'a new spatial language' that 'becomes the marker and the substitute of the unrepresentable totality' (p. 58). Thus 'space' is now effectively a word denoting the transcendental totality itself, both a phenomenal and a noumenal entity, and so becomes logically both 
subject and object of modernism. And the totality is imperialism, 'which stretches out the roads to infinity, beyond the bounds and orders of the national state' (p. 57). Jameson's final observation, though, resists dialectical closure:

if 'infinity' (and 'imperialism') are bad or negative in Forster, its perception, as a bodily and poetic process, is no longer that, but rather a positive achievement and an enlargement of our sensorium: so that the beauty of the new figure seems oddly unrelated to the social and historical judgement which is its content. (p. 58)

Imperialism maintains the modernist body and of the modernist intellect in an allegedly unresolved structural contradiction.

One does not have to share all of Jameson's presuppositions to recognise the brilliance and usefulness of his discussion. In drawing attention to the ways imperialism influenced metropolitan perceptions of domestic landscape, he opens up important new areas for research. He offers important and suggestive insights into the socio-economic matrices and meanings of modernist literary style. Two aspects emerge as particularly suggestive: Jameson's linkage of aesthetic indeterminacy to the operations of imperialism; and his demonstration of the ways in which empire can take on a metaphysical status. That significatory indeterminacy Jameson detects in Forster's Great North Road image, whereby empirical and transcendental, literal and figurative modalities stand in uneasy instrumental relationship with each other, each claiming subject and object status, can obviously be located in a number of contemporary cultural texts. Conrad's Heart of Darkness, title and text, plays out a similar semantic indeterminacy, as does Rider Haggard's She (who becomes grammatical and ideological subject and object of empire). These texts are, of course, directly engaged with the project of empire; the extension of Jameson's insights to other modernist texts remains to be made.

Said's discussion of Mansfield Park does not share Jameson's dialectical methodology. As a consequence, the contradictoriness of his different notions of space stand out, all the more so, ironically, because he characterises Austen's cultural production as expressive of a unified ideology, an ideology in fact centred on the values of social, moral and aesthetic cohesion, order and totality. Said's analysis aims at disclosing the dependency of Austen's metropolitan high culture on colonial possessions, more particularly on the slave plantations of the Caribbean. This important demystificatory project however ends up producing its 
own kind of mystique, in which the conviction that geographical territory is itself an ideology jostles with the counter-notion that spatial relations are pressed into the service of specific ideological, political and economic imperatives. The conflict, again, emerges from the mismatch of Said's Foucauldianism and his Gramscianism. For Said's analysis effectively identifies space or land as an independent source of social regulation and value-production whilst simultaneously suggesting that human agents and institutions confer such qualities upon the space in question.

Thus Said gives a compelling and persuasive account of how Sir Thomas's social and economic authority both legitimises and is legitimised by his possession of colonial space. Commenting on his departure from the Mansfield Park estate for Antigua, Said explains:

Whatever was wrong there ... Sir Thomas was able to fix, thereby maintaining his control over his colonial domain ... Austen here synchronises domestic with international authority, making it plain that the values associated with such higher things as ordination, law, and propriety must be grounded firmly in actual rule over and possession of territory. (p. 104)

Said's discussion of Sir Thomas's authority-constitution slides easily into a discussion of social value-constitution, concluding that 'to hold and rule Mansfield Park is to hold and rule an imperial estate in close, not to say inevitable association with it. What assures the domestic tranquillity and attractive harmony of one is the productivity and regulated discipline of the other' (p. 104).

This seems to me to conflate two separate issues, and with it two contending methodologies. That they are in tension is suggested directly by Said's own analysis of what happens to Mansfield Park 'while Sir Thomas is away tending his colonial garden' and establishing its 'productivity and regulated discipline': anarchy and amorality, not 'domestic tranquillity and attractive harmony', prevail in Mansfield Park (p. 102). Instead of guaranteeing the Park's aesthetic and social order, the colony can be seen to threaten it, by removing its requisite authority-figure.

The delinquency of Mansfield Park's wayward inhabitants is understood by Sir Thomas to arise from an inner deficiency, a lack of moral principle. This inner lack, Said argues, is filled by two outside forces: 'the wealth derived from a West Indian plantation' and 'a poor provincial relative', Fanny Price, both 'brought in to Mansfield Park and set to work' 
(p. 110). Said makes much of this formal movement in space, from the outside to the inside; the movements of Fanny and of wealth not only correspond to one another but also 'require each other' and further, require 'executive disposition' (p. 110). However, Said has already argued a very similar spatial relation between Fanny and Sir Thomas himself:

To earn the right to Mansfield Park you must first leave home as a kind of indentured servant ... but then you have the promise of future wealth ... Austen sees what Fanny does as a domestic or small-scale movement in space that corresponds to the larger, more openly colonial movements of Sir Thomas, her mentor, the man whose estate she inherits. The two movements depend on each other. (p. 106)

Herein lie a number of problems. Said has been tempted by the very spatiality, and aestheticism, he is concerned to demystify, leading him to attach ideological significance to formal patterns of movements through space. Establishing the existence of these patterns takes precedence over their internal and their external consistency; hence we are presented with two incompatible accounts of Fanny's status, neither of which is problemfree. To posit Fanny's spatial movements as corresponding to those of Sir Thomas is to overlook a crucial difference between them, already revealed in Said's own analysis. Sir Thomas moves about in space because he has power, Fanny moves about (or rather, is moved) in space because she lacks power. Fanny's movement in enables her to attain legitimation and authority, Sir Thomas's movement in and out is, as we have already seen, both constitutive and reflective of his authority. Fanny, Said is suggesting, resembles Sir Thomas in her upright moral qualities, which entitle her to eventual ownership of the estate. Her innate morality, Said argues, derives from her poverty. Morality, he implies, cannot inhere in those like her decadent cousins who do not have to labour for their wealth.

If this is the case, then it becomes difficult to accept the reasoning and the conclusions of Said's second formulation, in which Fanny is likened to the colony's wealth in being an outside force brought into Mansfield Park to supply what is 'wanting within'. If Fanny is aligned, through her spatial activity, with a colonial planter (the owner of production) she cannot at the same time and for the same reason be aligned with the wealth produced and owned by the planter. Said's first formulation, then, juxtaposes Fanny's poverty with her Mansfield Park cousins' wealthy upbringing; wealth is inherent to Mansfield Park and as such antithetical to the acquisition of morality. Said's second formulation reverses both the 
geographical location and the moral argument attached to wealth; wealth is something brought in from outside and is interdependent with the morality likewise imported through the figure of Fanny.

The inconsistencies here arise, as I have already argued, from Said's desire to accord space a constitutive ideological role. The foregrounding of space and movement through it as intrinsically meaningful allows powerless human subjects to be rendered conceptually interchangeable with powerful human subjects and with economic processes. Where Said's analysis is at its most valuable is in his persuasive demonstration of the conjunction of political and aesthetic ideological values in the Mansfield Park home estate. Fanny learns there the value of large, ordered spaces that express aesthetic harmony and its correlate socio-political propriety. That this aesthetic-political model is an essentially hierarchical one, necessitating an authoritarian administrator, Said makes clear. His argument that this hierarchical model is transposable to the estate's overseas colony is convincing; less so is his suggestion that the functioning of this model in Mansfield Park requires the existence of the colony.

Said and Jameson reveal a striking incuriosity about the social relations imposed upon colonised peoples, an incuriosity which extends to the colonised themselves. For Jameson, it seems, colonised peoples are conceivable only as an extension of the economic system that controls them. This underlies his suggestion that

The other pole of the relationship, what defines him [the 'Imperial type'] fundamentally and essentially in his 'imperial' function, - the persons of the colonized - remains structurally occluded, and cannot but so remain, necessarily, as a result of the limits of the system. (p. 58)

Consequently, he argues, the colonised can carry no direct purchase on metropolitan aesthetic consciousness but are representable only by proxy, either through symbols of capitalist power or through racialised Europeans. Thus, for instance, he argues of Howards End that 'Africa is set in place by the mediation of Charles Wilcox, who works in Uganda for his father's Imperial and West African Rubber Company' (p. 65). Arguing that during this era 'the word imperialism designates, not the relationship of metropolis to colony, but rather the rivalry of the various imperial and metropolitan nation-states among themselves' leads to Jameson's contention that the colonised Other is represented in 'high' culture through the demonised representation of another 'imperial nation state' such as 
Germany (p. 49). Zola's La Débâcle features Germans as 'physically alien and terrifying, barbarous, uncivilized, and still not terribly remote, as stereotypes, from the archaic "wild man of the middle ages"' (p. 49). This rests on assumptions that are empirically questionable, given that some modernist writings do contain direct representations of colonised peoples. ${ }^{14}$ Jameson's assumption is politically problematic, too, in its willingness to construct such an elision (of the human-subjective into the economic-objective) as automatically inevitable when it does occur.

For Said, 'slavery, economic depression, and rivalry with France' are grouped together as constituting what was (somewhat vaguely) 'at issue' in the possession of Caribbean colonies. None of these three particular definitions is in fact integral to his ensuing discussion of the meanings of colonial space within the novel. None the less this discussion does posit, even if it does not conclusively demonstrate, that 'right up to the last sentence, Austen affirms and repeats the geographical process of expansion involving trade, production, and consumption that predates, underlies, and guarantee [the novel's] morality' (p. 111).

To add to the sense of analytic disjunction, Said's closing comments in this section contend:

There is a paradox ... which I have been impressed by but can in no way resolve ... Everything we know about Austen and her values is at odds with the cruelty of slavery. Fanny Price reminds her cousin that after asking Sir Thomas about the slave trade, 'There was such a dead silence' as to suggest that one world could not be connected with the other since there simply is no common language for both. That is true ... In order more accurately to read works like Mansfield Park, we have to see them in the main as resisting or avoiding that other setting, which their formal inclusiveness, historical honesty, and prophetic suggestiveness cannot completely hide. (p. 115)

One can detect here, perhaps, Said's identification with Austen: sharing her values of honesty and inclusiveness, he is obliged to include (passing) mention of slavery at the risk of violating his/her values of aesthetic decorum. But what, one is entitled to ask, does the 'trade, production, and consumption' that 'underlies' the novel's morality consist in if not precisely the system of slavery? (p. 115). That Said should thus cursorily mention slavery attests less to the topic's fictional marginality than it does to his lack of desire to engage with the topic. Said's account of slavery's 'silence', then, colludes with that silence. 
Said's problematic treatment of slavery is part of a generally problematic presentation of economic processes. The narrative condition of economic wealth is that it be converted by Austen 'to propriety, order, and ... comfort'; for Said, it seems, the human basis of this wealth acquisition in slavery is not readily itself convertible to such aesthetic-political values (p. 108). Only an already abstracted, and rhetorically posited, notion of economic system can undergo the further abstraction of aesthetic conversion. Said's assertions about the way wealth functions in and for the novel thereby become undemonstrable and for that reason problematic.

Instead of arguing an economic aspect to inhere within such narratives, critics might explore the textual mechanisms whereby metropolitan writers such as Austen carefully exclude the economic aspects of their imperial subjects. In addition, critics might utilise a model of cultural representation that permits of more internal ideological contradiction and contestation than Said allows. This would enable a reading of Mansfield Park as containing, potentially, both oppositional and affirmative relations to empire. (A strongly oppositional reading issues from Moira Ferguson, whose conclusions are the antithesis of Said's. Ferguson contends an emergent abolitionism at work in the novel, derived from a mediatory concept of textual representation in which Fanny Price is stationed as slave surrogate.) 15

Both Said and Jameson, I suggest, foreground an aestheticised analysis of colonial space at the analytical expense of space's human occupants. They consequently minimise the historical function of violence in metropolitan culture and empire. Jameson's minimisation of violence meshes with a minimisation of the category of ideology. That he takes the physical senses of metropolitans to stand by definition totally outside of ideology is potentially a rather dangerous formulation, especially since these physical senses are alleged to affirm imperialism: the dangers of ascribing a biologically determined component to political practices need not be spelt out here. To introduce (economic, social and political) violence into Jameson's theorisations is to denaturalise much of what he effectively presents as physiologically natural and structurally inevitable. Thus, for instance, we can examine the violence of narratives that can represent colonised peoples only as non-human offshoots of capitalist production. The mechanics whereby metropolitan people equate imperialism with the entirety of human possibility are certainly violent, even if Jameson does not recognise this. 


\section{Conclusion}

Both the strengths and the weaknesses of Said, Jameson and Spivak here inspire future work on metropolitan, imperial cultures and subjectivities. They clear a path for materialist analysis of the ways in which the metropolis was, like the colonies, a heterogeneous site of hegemonic and counterhegemonic institutions, movements and subjectivities. Spivak's emphasis on sexual difference of imperial interpellation suggests how future work can explore the function of other kinds of difference in metropolitan ideological formations. Jameson's argument for the constitutive contradictions of Forster-at once rationally, and rhetorically, opposed to empire yet aesthetically affirmative of it - opens a number of theoretical and critical possibilities for future work on political rhetoric, its relations to imperial structures of feeling and aesthetics.

The work of these three attests in very different ways to the fruitfulness of attending to the international, economic, political and philosophical processes which feed imperial culture. Said's macrological approach reveals the complex challenge of accounting for the totality of imperial culture's formations. Spivak and Jameson invite critical exploration of the relative advantages of dialectical and categorical approaches to the analysis of imperial culture. In Jameson we witness a dialectical approach to the production of art-which is held to preserve and sublate its social determinants - conjoined with a resolutely empiricist, categorical formulation of human bodies and economies. These latter provide the material determinants of consciousness in a direct, unmediated manner; they remain for Jameson unconditioned by political and ideological processes. For Spivak, imperial culture directly illustrates philosophical theories of human subject-constitution, themselves corollary to political processes of territory-constitution. If Jameson's notion of imperial subject-constitution excludes the political, Spivak's excludes the economic. The categorical fixity of both constructions precludes apprehension of imperial subjectivity as a dynamic formation, interacting with both political and economic processes.

Finally, Spivak, Jameson and Said all draw attention to the need for materialist postcolonial criticism to engage theoretically with the topic of space and the ways it functions within imperial metropolitan culture. What emerges from their work is the challenge of producing an account that neither aestheticises space nor renders it a synonym for existential aporia but is sensitive both to phenomenological and political processes, to human production of as well as production within space. 


\section{Notes}

1 Aijaz Ahmad, In Theory: Classes, Nations, Literatures (London: Verso, 1992). For materialist critiques of this see Neil Lazarus, 'Postcolonialism and the Dilemmas of Nationalism: Aijaz Ahmad's Critique of Third-Worldism', Diaspora: A Journal of Transnational Studies, 2, 3 (1993), pp. 373-400, and Benita Parry's review article of Aijaz Ahmad's In Theory, History Workshop Journal, 36 (1993), pp. 232-41.

2 Francis Mulhern (ed.), Contemporary Marxist Literary Criticism (London: Longman, 1992), p. 97.

3 Terry Eagleton (ed.), Raymond Williams: Critical Perspectives (Cambridge: Polity Press, 1989), pp. 150-65.

4 The texts of this article's discussion are Edward Said, Culture and Imperialism (London: Chatto, 1993); Gayatri Chakravorty Spivak, 'Three Women's Texts and a Critique of Imperialism', in Henry Louis Gates Jr (ed.), 'Race', Writing and Difference (Chicago: University of Chicago Press, 1986) pp. 262-80; Fredric Jameson, 'Modernism and Imperialism', in Seamus Deane (ed.), Nationalism, Colonialism and Literature (Minneapolis: University of Minnesota Press, 1990), pp. 43-66. Jameson's essay was first published by Field Day Theatre Company (Derry, Northern Ireland) and this edition is titled a 'Field Day Company Book'. A version of Gayatri Spivak's essay can be found in her Critique of Postcolonial Reason: Toward a History of the Vanishing Present (Cambridge, MA, and London: Harvard University Press, 1999), pp. 112-40.

5 A useful discussion of Said's book is Bruce Robbins, Mary-Louise Pratt, Jonathan Arac, R. Radhakrishnan, and Edward Said, 'Edward Said's Culture and Imperialism: A Symposium', Social Text, 40 (1994), pp. 1-38. See also Paul Zeleza's critique: chapter 21 'The Tribulations of Undressing the Emperor', Manufacturing African Studies and Crises (Dakar: Codesria, 1997), pp. 478-93.

6 See for example Eric Hobsbawm, The Age of Empire: 1874-1914 (London: Weidenfeld and Nicolson, 1987); John M. MacKenzie, Propaganda and Empire: The Manipulation of British Public Opinion, 1880-1960 (Manchester: Manchester University Press), 1984; John M. MacKenzie (ed.), Imperialism and Popular Culture (Manchester: Manchester University Press, 1986).

7 For a discussion of Spivak's Indiacentrism and its implications for the analysis of African imperialism see Laura Chrisman, 'The Imperial Unconscious? Representations of Imperial Discourse', Critical Quarterly, 32, 3 (1990), pp. $38-58$.

8 See for instance Said, Culture and Imperialism, p. 10, p. 114, p. 128.

9 See Ibid., p. 119, p. 127.

10 Ibid., p. 40, p. 84.

11 The tensions between Said's Foucauldianism and his Gramscianism are also evident in his Orientalism, as observed by Dennis Porter, 'Orientalism and Its Problems', in Patrick Williams and Laura Chrisman (eds.), Colonial 
Discourse and Post-colonial Theory: A Reader (Hemel Hempstead: Harvester, 1993), pp. 150-61.

12 See Bernard Porter, Critics of Empire: British Radical Attitudes to Colonialism in Africa, 1895-1914 (London: Macmillan, 1968).

13 For a suggestive account of Gramsci's uses in the related studies of ethnicity, see Stuart Hall, 'Gramsci's Relevance for the Study of Race and Ethnicity', in David Morley and Kuan-Hsing Chen (eds.), Stuart Hall: Critical Dialogues in Cultural Studies (London: Routledge, 1996), pp. 411-40.

14 The most obvious example is Forster's own A Passage to India; Jameson's explanation on pp. 65-6 of how this novel conforms to his scheme is unconvincing, based as it is on the dubious contention that Hindus are 'specifically designated as that Other, inaccessible to Western representation'.

15 Moira Ferguson, 'Mansfield Park: Slavery, Colonialism and Gender', Oxford Literary Review, 13 (1991), pp. 118-39. 